UDK 528.44

\title{
SELECTED LEGAL ISSUES OF LAND CADASTRAL SURVEYING IN LITHUANIA
}

\author{
Vladislovas Česlovas AKSAMITAUSKAS ${ }^{1}$, Kristina GRINEVIČIŪTÉ2 \\ ${ }^{1}$ Department of Geodesy and Cadastre, Faculty of Environmental Engineering, \\ Vilnius Gediminas Technical University, Sauletekio al. 11, LT-10223, Vilnius, Lithuania \\ ${ }^{2}$ Institute of Criminal Law and Procedure, Faculty of Law, Mykolas Romeris University, \\ Ateities g. 20, LT-08303, Vilnius, Lithuania \\ E-mail: ${ }^{1}$ ceslovas.aksamitauskas@vgtu.lt (corresponding author)
}

\section{Received 13 February 2015; accepted 20 May 2015}

\begin{abstract}
This study is limited to the selected problematic aspects of cadastral surveys of land plots. Special attention is paid to the problem of on-site marking of the land plot boundaries. Authors have found that it determine imperative and complicated legal regulations. Cases where the act of marking-demonstration of the land plot boundaries is declared faulty in judicial practice are discussed. The problems of establishing the land plot boundaries are considered. Theoretical analysis is based on judicial practice. The advanced judicial practice demonstrates that immovable object cadastral surveys cannot correct legal ownership relationships.
\end{abstract}

Keywords: land law, real property cadastre, land cadastre, cadastral (geodetic) surveying, cadastral measurements, cadastral data, land surveyor, a plot of land.

\section{Introduction}

Cadastral (geodetic) survey is carried out to establish cadastral data of land plots. According to the Paragraph 3 of Article 8 of the Law of Real Property Cadastre, the delimitation of the cadastral data for a land plot is a continuous process consisting of series of actions aimed at: determination and marking with landmarks (if it was not made previously) of land plot boundaries; by cadastral measurement marking the coordinates of the curve points of the plot boundaries, landmarks and building contours in the national coordinate system; cartographing of actual land use; calculation of total land plot area and sub-areas; preparation of the land plot plan; calculation of the land plot value; filling the form of the land plot cadastral data; preparation of a cadastral data case for immovable objects (Lietuvos Respublikos Nekilnojamojo turto... 2000).

Cadastral survey of land plots is a set of technical and legal actions. A number of publications about technical cadastral measurement aspects are available in literature (e.g. Skeivalas, Aleknienė 2004), but only few contain discussions on legal aspects of the quality of cadastral data cases (e.g. Jonauškiené, Demčiuk 2009; Vaitkevičienè, Kumetaitienè 2010). There are no doubts that cadastral measurements of land plots include series of legal procedures aimed at coordinating the interests of the involved parties (owners, stakeholders, authorities, etc.). An independence of the surveyor is clearly restricted. The majority of issues are regulated by imperative legal norms, and the court actively supervises the course of procedures.

It should be noted that no published research is available on the suitability of legal regulations for land plot cadastral surveys in Lithuania. Moreover, literature lacks publications related to the evaluation of current judicial practice of this issue. Since courts in Lithuania analyze in detail all procedural issues of land plot cadastral measurements, it is possible to identify some actions (procedures) that are the reasons for the occurring errors.

The object of the paper is land cadastral surveying and issues of their legal assessment. The main aim of the research is to assess the regulation of invitation of invitees for participation in the marking of land plot boundaries. To reveal the importance of the act of marking- demonstration of the land plot and issues of their assessment in judicial practice. To highlights problems of opportunity to change cadastral data of the adjacent land plot. 
Method of document analysis was the most broadly used method in the paper. Different documents, such as legislation of the Republic of Lithuania, judicial decisions were used as the main sources of information according to this method. The aim of the analysis of the documents was to identify and generalize the problematic aspects of the land cadastral surveying in Lithuania, to evaluate the effectiveness of legislation. To conduct the research the other research methods of social sciences were used: system, logic and etc.

\section{Problems regarding the marking of land plot boundaries}

The main and common error of cadastral survey is the marking of land plot boundaries. On-site marking of land plot boundaries is an exclusive and probably the most important procedure. This is because the on-site marking of boundaries is directly related to the rights and interests of other persons (owners of adjacent land plots or interested persons, etc.). Courts have repeatedly notified that the marking procedure should be implemented in reality, i.e. on-site (Vilniaus miesto 2 apylinkès teismo... 2011). Legal acts clearly state that the land plot boundaries are established and marked with landmarks during the implementation of the land plot cadastral measurements.

Another essential component of this procedure is invitation of invitees for participation in the procedure. Legal acts regulate in detail the circle of invitees, documents serving procedure (invitations, extracts from a land plot plan, etc.), whereas one of the main objectives of this action is to create an opportunity for the owners of adjacent land plots and interested persons to receive detailed information, related to the land plot boundaries.

Paragraph 32. 1. 1. of the Real Property Cadastre Regulations (Lietuvos Respublikos nekilnojamojo turto... 2002) imperatively establishes that the on-site marking of the land plot boundaries should be carried out in the presence of the land plot owner (current or future) or by him/her authorized person, as well as other concerned persons, such as owners of the adjacent land plots or by them authorized persons, trustee (s) of the adjacent state-owned or municipal land area that does not have an individual land plot status according to the territory planning document or land ownership project, chairman of the Gardeners Association, if the measured land plot boarders with the land of the Gardeners Association. The above listed entities shall be considered the invitees.
According to the new legal regulation model (entered into force on 7 April 2014), the marking procedure requires a mandatory participation of the Chairman of the Gardeners Association during the implementation of the cadastral survey of land plots that are located within the land of the Gardeners Association (Teisès aktų registras 2014). It should be noted that chairmen of the board of the Gardeners Associations have repeatedly expressed their wish to participate in amateur cadastral surveys of plots located within the territory of the gardens (Nacionalinè žemès tarnyba prie Žemès ūkio ministerijos). This regulation is highly favourable to the chairmen of the Gardeners Associations, but it raises doubts whether or not it ensures the balance between the interests of all parties, prevents conditions for violation of interests of other parties, and prevents additional beaurocracy and procedure delays.

Considering the legal culture in Lithuania, common disputes between the members of the Gardeners Association regarding boundaries of land plots, their intention to make impact on land surveyors and other parties, it cannot be guaranteed that participation of the chairman of the Gardeners Association in carrying out cadastral surveys would reduce the number of abuse cases. We believe that such regulation has an impact on additional expenses and work load of the land surveyor, does not prevent, but only increases, the probability of disputes and complicates the already extensive procedure.

In the legal regulation of the marking procedure one can also see several other aspects to discuss. First of all, it regards the serving of invitations or other documents to the invitees. It is generally accepted that the serving should be carried out strictly following the requirements of legal acts, i.e. the regulated serving methods and terms should be observed. According to Regulations of Real Property Cadastre Paragraph 32.1.1.2. (Lietuvos Respublikos Nekilnojamojo turto... 2002) the following serving methods are established: personal serving; sending be registered mail; publication in a local newspaper or on the advertising board of the subdistrict, where the works are planned (Lietuvos Respublikos Nekilnojamojo turto kadastro įstatymas 2000). Serving by publication (in a local press or on the subdistrict advertising board) provides the least opportunities for the addressee to study the respective documents. Therefore this method should be used only after all mandatory and reasonable means for detection of the place of residence (employment) 
of the addressees or serving of documents using other methods have been applied. This method is an exception, rather than a rule.

According to the authors, the rules on serving of documents established in the Real Estate Cadastre Regulations should help to ensure, as much as possible, that the person receives the real, not just formal, opportunity to study the content of the served documents. It should also ensure the opportunity for addressees to study and participate in the actions in progress. It is assumed that the method of publication in a local newspaper and on the advertising board of the subdistrict where the works are planned, should be replaced in the Real Estate Cadastre Regulations with other serving methods, established in other legal acts. For example, it should be done by serving through a legal officer and using the last resort measure, i.e. using the method of publication in press.

Proper realization of the document serving following the requirements established in legal acts is a mandatory condition for acknowledging the cadastral data cases proper. For example, in one case the court established that the person was not properly invited to the land plot marking works, because the invitation to participate in on-site land plot marking on 25-01-2008 was sent too late, i.e. on 22-01-2008, breaching the 10 days term, established in the regulations (Vilniaus apygardos teismo ... 2012).

In the other case, the court recognized that the land surveyor breached the procedure, established in legal acts, and deprived the applicant of the opportunity to provide comments, following the procedure established in paragraphs 29.8.5, 29.9 of the Real Property Cadastre regulations, because the invitation to the works on marking of boundaries of the land plot on 27-03-2008, was served to the owners of adjacent plots by hanging the invitations on the nearby located houses (Šiauliu apygardos... 2009).

Another example from the judicial practice is when informing the owners of the adjacent land plots about measurements in progress, wrong surnames were specified. The address was not found in the database according to the wrongly spelled surname, so the letter was sent to the land plot address, where the person did not actually reside. Furthermore, information about the measurements was not publicly published, therefore the information about the measurements in progress was not actually known by the owners of the adjacent land plots. The court stated that the specification of cadastral data was carried out without following the requirements established in the law (Traku rajono... 2014).
Improper serving of invitations or other documents to the persons is one of the main reasons when courts recognize that cadastral case is improper. The provided examples of judicial practice demonstrate crude violations of the procedure. It shall be mentioned that not every formal violation of the abovementioned procedure is the basis for recognition of the action illegal. In judicial practice it is recognized that the basis for cancellation of the disputed action can only be such procedural violations that lead to a non-objective evaluation of circumstances and to an unjustified decision (action). In every case the court assesses why the invitation was not served, what efforts were made to serve the document, what serving method was selected and whether there were violations of other processes (case completing, or etc.) or not, etc.

Another problem, related to the invitation serving, is more general. There are different opinions on what can be considered as a timely serving of documents. Some state that for the serving to be considered proper, it is enough to serve procedural documents formally following the requirements of the law. However the real opportunity to study the content of the served document is not considered (Žemès ūkio ministerijos... 2013). Others suppose that serving is considered timely, when the person is actually given an opportunity to study the content of the served document.

The regulated procedure on serving of invitations should be strictly followed. The certificate with a record that the documents were served to the person, referring to the legal act that it is enough to send the document to the addressee, is not always the basis for the conclusion that the invitee was properly informed. In one case the court established that it can be seen from the cadastral data case that the surveyor has sent the invitation by registered mail regarding the coordination of the land plot boundaries, however the applicant failed to collect the letter from the mail office. There is no record in the case that the invitation was repeatedly sent to the applicant or served using other methods. Even though the invitation was sent formally without violation of Paragraph 32.1.1.2. of the Regulations, the records confirm that the applicant was not actually informed about marking of boundaries of the adjacent land plot (Kauno apygardos administracinio teismo... 2013). After establishment of violations of several other procedures of this case, the court stated that the surveyor failed to fulfill all mandatory procedures, established in the Regulations. 
According to the authors, the formal informing (offering to study the document) of the person is sufficient even without considering whether the person had the real opportunity to study the content of the served document or not. The document serving is considered legal and causes respective legal consequences if two conditions are fulfilled: a) the procedure is fulfilled following the requirements of the regulations (terms and established methods); and b) serving (sending) is confirmed following the established procedure. This approach would ensure that the process is carried out without unreasonable delays and does not provide opportunities for the persons who fail to serve the documents to abuse the process.

\section{Assessment of the act of marking-demonstration of the land plot boundaries in judicial practice}

After on-site marking of the land plot boundaries, The Act of Marking-Demonstration of the Land Plot Boundaries is created. Judicial practice especially focuses on the importance of this Act. The Supreme Court of Lithuania has stated that the Act of Marking-Demonstration of the Land Plot Boundaries is a mandatory cadastral survey document, which is the integral part, or a component, of the Land Plot Cadastral Data Case. The Land Plot Geodetic Measurement Plan can be prepared only if the properly executed Act of MarkingDemonstration of the Land Plot Boundaries is available. Only then the competent authorities can approve the Land Plot Plan, and the land plot cadastral survey can be specified in the Public Register (Lietuvos Aukščiausiojo Teismo... 2009).

On-site marking of boundaries of a certain land plot should be carried out on the established date, i.e. the Act of Marking-Demonstration of the Land Plot Boundaries should include the date, indicating when this action was actually carried out.

In one case R.V. was invited to participate in marking of the adjacent land plot boundaries and signing the Act of Marking-Demonstration of Boundaries on 18 June 2008. R.V. failed to arrive on the set time. The Court stated that the marking of the land plot boundaries actually took place on 2 February 2006, and R.V. was not properly informed following the procedure established in legal acts. There is no evidence in the case about a new marking of the land plot boundaries on 18 June 2008, when R.V. was invited, and that the new Act of Marking-Demonstration of Boundaries was composed. The court stated that in that case there had to be a new Act of Marking-Demonstration of the Land Plot
Boundaries, including the data that were obtained on 18 June 2008, i.e. the Act had to include the actual date of implementation of actions and act signing. The unimplemented Act of 2 February 2006 could not be used for this purpose (Lietuvos vyriausiojo administracinio... 2010).

The attention should be paid to one more important aspect, namely, the signing of the Act of MarkingDemonstration. It should be signed by eligible persons. In practice there are cases when The Act of MarkingDemonstration of Boundaries of the land plot, which boarders with the land plot of J. $\check{C}_{\text {., }}$ was coordinated with J. K., who had nothing to do with the land plot in dispute. The court argued that such violation of the land plot preparation is considered essential, violating rights and lawful interests of J. $\check{C}$., and this cannot be interpreted as a simple error (Kauno apygardos teismo... 2013).

In other cases it was emphasized that the failure to participate in composing the Act of Marking-Demonstration does not necessary mean the falseness of this Act. For example, I. K. stated that the Act of Marking-Demonstration was illegal, because the person was not informed about marking of the adjacent land plot. The court established that the notification about geodetic measurements was sent to I. K. by mail. Considering the fact that the boundaries marked in preliminary measurements, the land plot privatization documents and other initial documents characterizing the land plot, were approved during marking of the adjacent land plot boundaries, the court decided that the circumstance of non-participation of I. $K$. in marking of the adjacent land plot boundaries did not provide the basis for the statement that the rights and lawful interests of $I . K$. were violated (Lietuvos Aukščiausiojo Teismo... 2011).

It shall be noticed that the Act of Marking-Demonstration of the Land Plot Boundaries is a mandatory cadastral survey document requiring a special attention filling it. This Act shall include the date indicating when the action was actually carried out and it should be signed (coordinated) by the persons listed in legal acts. When Act of Marking-Demonstration of the Land Plot Boundaries is composed properly, the courts do not have basis for doubts regarding its lawfulness. The Land Plot Plan can be prepared only with the properly executed Act of Marking-Demonstration of the Land Plot Boundaries.

\section{Aspects of delimitation of a land plot}

A problem related to marking of the land plot boundaries is embedded in item 2 of Paragraph 4 of Article 17 
of the Law of Real Property Cadastre. This provision of the Law imperatively regulates that the boundaries of land plots on the real property cadastre map should not cross the boundaries of adjacent and already marked on the real property cadastre map land plots. An exception is cases when the boundaries of these land plots were established more accurately by cadastral measurements implemented following the procedure established in the Cadastre Regulations. The Law provision enables the correction of the boundaries of the already registered and marked on the cadastre map land plot only when the boundaries of the land plot were established with the lower accuracy than that required for the newly marked boundaries of the land plot. A logic conclusion would be such that if the boundaries of both land plots were established with the same accuracy, corrections are not permitted.

It often happens in practice that while establishing cadastral data of one land plot the land surveyor changes cadastral data of the other (adjacent) land plot (boundary, coordinates of landmarks, area, etc.). In such cases courts often cancel the newly established cadastral data and legal basis for their change. For example, cadastral data of land plot No. 21A were established on 6 April 2005, and they were registered in the Real Property Cadastre. Cadastral data of land plot No. 22, owned by V. N., were corrected according to the newly established cadastral data in 2011 and following the order of Land Administration Department of the National Land Service under the Ministry of Agriculture of 28 December 2011 on correction of cadastral data. Boundaries of land plot No. 22 cross boundaries of land plot No. 21A. In this case, the court cancelled the order of 28 December 2011 as non-conforming to item 2 of paragraph 4 of Article 17 of the Law of Real Property Cadastre and paragraph 21 of the Regulations of Real Property Cadastre, and made several important conclusions:

- While establishing cadastral data one shall follow justice presumption of the data, registered in the Real Estate Cadastre, established in paragraph 4 of Article 3 of the Law on Cadastre of the Real Estate, which provides that the data registered in the real Estate Cadastre are considered accurate and detailed on their registration moment, until they are changed or disputed following the procedure established by law;

- Establishment or correction of cadastral data cannot change the legal status of an immovable object;

- Subjective right of a civil character of one person cannot be unilaterally established for determina- tion or correction of cadastral data by denying the same right of another person, as well as the disputed right of the other person cannot be unilaterally defended (Lietuvos vyriausiojo administracinio... 2013).

The court decision in the above mentioned case may require more comment. Such judicial practice, emphasizing accuracy and completeness of cadastral data, is lawful, because the ownership right is absolute and defended by the Constitution.

The court encountered similar situation while examining the administrative case, where by correction of one land plot boundaries by the administrative act (order of the National Land Service under the Ministry of Agriculture), the area of the adjacent land plot decreased. The court unambiguously stated that the land plot area cannot be reduced by correction of cadastral data following the administrative procedure, as this caused negative consequences to the person due to the decreased area of his owned land plot, and the transaction granting the person a right to the certain land plot area cannot be changed by the administrative act and can be disputed in the court (Lietuvos vyriausiojo administracinio... 2014).

Cadastral surveys of an immovable object is not a process for its own sake, it is aimed at establishing the cadastral data of the immovable object. The advanced judicial practice demonstrates that the cadastral measurements of immovable objects cannot correct legal ownership relationships. Cadastral data of the adjacent land plot (registered in the Real property Cadastre) cannot be changed without a legal basis. The land surveyor does not have mandate to dispute the cadastral data of the registered immovable object, all the more to change them without consent of the owner. Inaccuracy of the registered land plot cadastral data can be established only by the court.

\section{Conclusions}

1. The main and common error of a cadastral survey is marking of land plot boundaries. This procedure is complicated by imperative and complicated legal regulations, related to serving of invitations or other documents to the invitees. Serving of documents is a complicated and problematic process. Failing to meet the requirements of legal acts is one of the main reasons for the courts to declare the cadastral data case to be improperly prepared.

2. The Act of Marking-Demonstration of the Land Plot Boundaries is a mandatory cadastral survey 
document, therefore a special attention should be paid to filling it. This Act should include the certain date, demonstrating when the action was actually carried out; it shall be signed (coordinated) by the persons listed in legal acts. When Act of Marking-Demonstration of the Land Plot Boundaries is composed properly, the courts do not have basis for doubts regarding its validity. The Land Plot Plan can be prepared only with the properly executed Act of Marking-Demonstration of the Land Plot Boundaries.

3. Cadastral surveying of the immovable object is not a process for its own sake, it is aimed at establishing the cadastral data of an immovable object. The advanced judicial practice demonstrates that immovable object cadastral surveys cannot correct legal ownership relationships. Cadastral data of the adjacent land plot (registered in the Real Property Cadastre) cannot be changed without a legal basis. The surveyor does not have mandate to dispute the cadastral data of the registered immovable object, all the more to change them without consent of the owner.

\section{References}

Jonauškienè, I.; Demčiuk, S. 2009. Daugiakriterinès analizès taikymas žemès sklypų kadastro duomenų kokybei vertinti [The Application of Multi-Criteria Analysis to Quality Assessment of Land Parcels Cadastral Data], Geodezija ir kartografija - Geodesy and Cartography 35(2): 66-71.

http://dx.doi.org/10.3846/1392-1541.2009.35.66-71

Kauno apygardos administracinio teismo $2013 \mathrm{~m}$. lapkričio 26 d. sprendimas administracineje byloje Nr. Ik-58-554/2013. [Kaunas Regional Administrative Court decision of 26 November 2013 in case No Ik-58-554-2013] [online] Vilnius [cited 13 January 2015]. Available from Internet: http://eteismai.lt/byla/97090858134744/Ik-58-554/2013

Kauno apygardos teismo $2013 \mathrm{~m}$. birželio $12 \mathrm{~d}$. nutartis civilineje byloje Nr. 2A-796-413/2013. [Kaunas Regional Court decision of 12 June 2013 in case No 2A-796-413-2013], [online] Vilnius [cited 13 January 2015]. Available from Internet: http://eteismai.lt/byla/68715186548527/2A-796-413/2013

Lietuvos Aukščiausiojo Teismo 2009 m. gegužès 29 d. nutartis civilineje byloje Nr. 3K-3-226/2009. [The Supreme Court of Lithuania decision of 29 May 2009 in case No 3K-3-2262009], [online] Vilnius [cited 13 January 2015]. Available from Internet: http://eteismai.lt/byla/82070445139942/ 3K-3-226/2009

Lietuvos Aukščiausiojo Teismo $2011 \mathrm{~m}$. vasario 7 d. nutartis civilineje byloje Nr. 3K-3-35/2011. [The Supreme Court of Lithuania decision of 7 February 2011 in case No 3K-3-352011], [online] Vilnius [cited 13 January 2015]. Available from Internet: http://eteismai.lt/byla/252741507131431/ 3K-3-35/2011

Lietuvos Respublikos nekilnojamojo turto kadastro įstatymas [Law of Real Property Cadastre of the Republic of Lithuania]. 2000. Valstybés žinios [Lithuanian News], 58-1704.

Lietuvos Respublikos nekilnojamojo turto kadastro nuostatai [Regulations of Real Property Cadastre of the Republic of
Lithuania]. 2002. Valstybès žinios [Lithuanian News], 411539.

Lietuvos vyriausiojo administracinio teismo 2010 m. lapkričio 12 d. nutartis administracinèje byloje Nr. A438-1455/2010. [Supreme Administrative Court of Lithuania decision of 12 November 2010 in case No A-438-1455-2010], [online] Vilnius [cited 13 January 2015]. Available from Internet: http:// eteismai.lt/byla/261406264425341/A-438-1455-10

Lietuvos vyriausiojo administracinio teismo $2013 \mathrm{~m}$. balandžio 29 d. nutartis administracineje byloje Nr. A-442-55/2013. [Supreme Administrative Court of Lithuania decision of 29 April 2013 in case No A-442-55-2013], [online] Vilnius [cited 13 January 2015]. Available from Internet: http://eteismai.lt/byla/111394236122722/A-442-55-13

Lietuvos vyriausiojo administracinio teismo $2014 \mathrm{~m}$. rugsèjo 29 d. sprendimas administracineje byloje Nr. A261-977/2014. [Supreme Administrative Court of Lithuania decision of 29 September 2014 in case No A-261-977-2014], [online] Vilnius [cited 13 January 2015]. Available from Internet: http:// eteismai.lt/byla/216513327998461/A-261-977-14

Nacionalinè žemès tarnyba prie Žemès ūkio ministerijos [National Land Service under the Ministry of Agriculture], [online] Vilnius [cited 13 January 2015]. Available from Internet: http://www.nzt.lt/go.php/lit/Del-sodininku-bendrijos-pirmininko-dalyvavimo-atliekant-megejiko-sodoteritorijoje-sodo-sklypo-kadastrinius-matavimus

Skeivalas, J.; Aleknienè, E. 2004. Koordinačių matavimo tikslumas, nustatant kadastrinių sklypų plotus [Coordinate measurement accuracy, while establishing areas of cadastral plots], Geodezija ir Kartografija - Geodesy and Cartography 30(3): 71-74.

Šiaulių apygardos administracinio teismo 2009 m. lapkričio 30 d. sprendimas administracineje byloje Nr. I-219355/2009. [Šiauliai Regional Administrative Court decision of 30 November 2009 in case No I-219-355-2009], [online] Vilnius [cited 13 January 2015]. Available from Internet: http://eteismai.lt/byla/243240903613650/I-219-355/2009

Teisès aktų registras [Register of Legal Acts], 2014. Nr. 303, paskelbta 2014-04-07 [published 07-04-2014], [online] Vilnius [cited 13 January 2015]. Available from Internet: https://www.e-tar.lt/portal/lt/legalAct/3524c8a0be4911e387 66a859941f6073

Trakų rajono apylinkès teismo $2014 \mathrm{~m}$. kovo $4 \mathrm{~d}$. sprendimas civilinèje byloje Nr. 2-14-804/2014 [Traku District Court decision of 4 March 2014 in case No 2-14-804-2014]. [online] Vilnius [cited 13 January 2015]. Available from Internet: http://eteismai.lt/byla/58499400494713/2-14-804/2014

Vaitkevičienė, J; Kumetaitienè, A. 2010. Kadastrinių matavimų tikrinimo ir derinimo probleminiai aspektai [Problematic aspects of cadastral surveying revising and adaptation], Žemetvarka ir hidrotechnika - Land use planing and hydrotechnics 3: 40-47.

Vilniaus apygardos teismo $2012 \mathrm{~m}$. gegužès $12 \mathrm{~d}$. nutartis civilineje byloje 2A-1777-467/2012 [Vilnius County Court decision of 12 May 2012 in case No 2A-1777-4672012], [online] Vilnius [cited 13 January 2015]. Available from Internet: http://eteismai.lt/byla/125216596770388/ 2A-1777-467/2012

Vilniaus miesto 2 apylinkès teismo $2011 \mathrm{~m}$. gegužès $2 \mathrm{~d}$. sprendimas civilineje byloje Nr. 2-1766-817/2011. [The District Court of Vilnius City decision of 2 May 2011 in case No 2-1766-817-2011]. 
Žemès ūkio ministerijos 2013-07-10 raštas Nr. 2D-3527(12.144) [The Ministry of Agriculture document of 10 July 2013] [online] Vilnius [cited 13 January 2015]. Available from Internet: http://www.matininkuasociacija.lt/uploads/documents/dokumentai/20130710_zum_rastas.pdf

Vladislovas Česlovas AKSAMITAUSKAS, Prof. Dr, Head of Department of Geodesy and Cadastre, Faculty of Environmental Engineering, Vilnius Gediminas Technical University, Sauletekio al. 11, LT-10223 Vilnius, Lithuania.

Author of 60 scientific papers. Research interests: engineering structures deformation analysis by geodesy methods.

Kristina GRINEVIČIŪTĖ, Lecturer at the Institute of Criminal Law and Procedure, Faculty of Law, Mykolas Romeris University, Ateities g. 20, LT-08303 Vilnius, Lithuania.

A graduate from Vilnius University (Master of Science 2002). The author of 7 scientific papers. Research interests: real property law, crimes and misdemeanors against child and family. 